\title{
KEJAYAAN MODAL INSAN DAN INOVASI DALAM PENTADBIRAN MAHKAMAH SYARIAH: MEMBINA MODEL ANTARABANGSA*
}

\section{Achievements of Human Capital and Innovation in the Administration of Shariah Court: Aiming for An International Model}

\author{
Ramizah Wan Muhammad ${ }^{1}$ \\ Khairunnasriah Abdul Salam²
}

\begin{abstract}
This article highlights the achievements of Shariah Courts in Malaysia in administering Islamic law especially on the issues of human capital as well as innovations which were introduced by the Department of Shariah Judiciary, Malaysia (JKSM) and the State Department of Shariah Judiciary (JKSN). This study
\end{abstract}

* Penulis merakamkan setinggi-tinggi penghargaan kepada Tuan Haji Mohamad Shakir Abdul Hamid dan YAA Tuan Abas Nordin dari Jabatan Kehakiman Syariah Malaysia (JKSM), Putrajaya di atas maklumat yang diberikan dalam melengkapkan kajian ini.

1 Associate Professor, Department of Islamic Law, Ahmad Ibrahim Kuliyyah of Laws, International Islamic University Malaysia, P.O. Box 10, 50728 Kuala Lumpur,ramizah@iium.edu.my

2 Postgraduate and Research Unit, Ahmad Ibrahim Kuliyyah of Laws, International Islamic University Malaysia, P.O. Box 10, 50728 Kuala Lumpur, nasriah. abdulsalam@gmail.com 
also aims at fending off some negative notions against the Shariah Court as the second-class court in terms of power and achievements in administering and implementing Islamic law in Malaysia. The study uses qualitative approach and refers as well to the primary and secondary sources, which includes statutory provisions, monograf, articles, website information and interview with Tuan Haji Mohammad Syakir Abdul Hamid, the Registrar, JKSM at that time. The study found that the efforts made by $J K S M / J K S N$ have, in the above-mentioned areas, achieved the goal and received recognition at the international level.

Keywords: Shariah Court, innovation, human capital, Malaysia

\section{PENGENALAN}

Sistem perundangan Islam dan institusi kehakiman Islam telah bertapak di Tanah Melayu sekitar kurun ke-12 seiring dengan kedatangan agama Islam ke Tanah Melayu. ${ }^{3}$ Semasa kurun ke-14, sistem perundangan dan institusi kehakiman Islam lebih berkembang apabila Kesultanan Melayu Melaka mengangkat agama Islam sebagai agama rasmi dan mengguna pakai undangundang Islam dalam pentadbirannya. ${ }^{4}$ Walau bagaimanapun, pemakaian sistem perundangan dan kehakiman Islam di Tanah Melayu tergugat selepas kedatangan British ke Tanah Melayu yang mula campur tangan dalam hal ehwal pentadbiran di Tanah Melayu dengan memindahkan kuasa pentadbiran daripada Raja-raja Melayu kepada Residen British kecuali dalam urusan agama Islam dan adat-istiadat Melayu. ${ }^{5}$

Secara asasnya, makalah ini membincangkan sejarah pentadbiran Mahkamah Syariah di Malaysia secara ringkas. Seterusnya, makalah ini turut menyorot kejayaan pentadbiran Mahkamah Syariah di Malaysia, terutamanya selepas kewujudan JKSM dalam konteks kemampanan modal insan dan inovasi yang telah dibuat oleh JKSM dan JKSN. Kejayaan modal insan yang dibincangkan dalam makalah ini menjurus kepada aspek kualiti kakitangan dalaman di Mahkamah Syariah dan JKSM serta JKSN yang menjadi teraju

3 Ramizah Wan Muhammad, 'The Administration of Syariah Court in Malaysia, 1957-2009,' Journal of Islamic Law and Culture, vol. 13, no. 2-3 (2011): 241-242.

4 Naquib al Attas, Preliminary Statement on A General Theory of the Islamicization of the Malay-Indonesian Archipelago (Kuala Lumpur: Dewan Bahasa dan Pustaka, 1969), 12.

5 Ramizah Wan Muhammad, 'The Administration of Syariah Court in Malaysia, 1957-2009,' 244. 
kejayaan pentadbiran Mahkamah Syariah. Manakala, kejayaan inovasi yang diketengahkan dalam makalah ini menjurus kepada pencapaian apa-apa sahaja pembaharuan yang dilakukan di Mahkamah Syariah sama ada dalam bentuk sistem teknologi maklumat mahupun tidak yang menyokong gerak kerja kakitangan dalaman tersebut atau memberi impak positif terhadap kejayaan modal insan dalam pentadbiran di Mahkamah Syariah, JKSM dan JKSN.

Seterusnya, makalah ini mengemukakan pandangan bahawa pentadbiran Mahkamah Syariah di Malaysia berpotensi untuk terus mandiri sebagai institusi kehakiman Islam yang professional dan progresif berdasarkan kejayaan yang dicapai dalam aspek modal insan dan inovasi-inovasi yang telak dilaksanakan. Hal ini sekali gus menjadikan pentadbiran Mahkamah Syariah di Malaysia sebagai suatu model pada peringkat antarabangsa bagi memartabatkan lagi undang-undang Islam pada kaca mata global.

\section{PENTADBIRAN MAHKAMAH SYARIAH DI MALAYSIA}

Kedudukan agama Islam di Malaysia ditetapkan oleh Perlembagaan Persekutuan yang mana Islam merupakan agama persekutuan, tetapi agamaagama lain boleh diamalkan secara aman dan damai di Malaysia sebagaimana yang termaktub dalam Perkara 3(1) Perlembagaan Persekutuan. Pelbagai tafsiran dibuat mengenai maksud Perkara 3(1) ini. Ada yang menyatakan bahawa agama Islam hanya agama bagi negara dan Malaysia bukanlah negara Islam seperti yang difahami oleh masyarakat umum. Mengikut Prof. Ahmad Ibrahim, kesan peruntukan Perkara 3 ini bukanlah bermaksud bahawa agama Islam hanya digunakan atau diamalkan dalam upacara rasmi, bahkan unsurunsur Islam mesti diterapkan lebih dari itu. ${ }^{6}$ Perkara 3 (1) dalam Perlembagaan Malaysia ini adalah berkait rapat dengan sejarah kedudukan agama Islam pada zaman kesultanan Melaka sebelum berlakunya penjajahan British di negara kita. Dengan kata lain, peruntukan ini adalah satu pengiktirafan bahawa prinsip atau pegangan yang dipegang oleh orang Melayu sebelum kedatangan British ialah agama Islam. ${ }^{7}$

Penubuhan dan bidang kuasa Mahkamah Syariah di Malaysia adalah berdasarkan bidang kuasa yang termaktub dalam Senarai Negeri dalam Jadual 9 Perlembagaan Persekutuan yang memperuntukkan bahawa hukum Syarak serta undang-undang diri dan keluarga (personal laws) bagi penganut Islam

6 Nik Ahmad Kamal Nik Mahmood, 'Kedudukan Undang-Undang Islam dalam Perlembagaan Malaysia,' Al Ahkam, vol. 4 (1994), 2-3.

7 Faiza Thamby Chik, 'Malay and Islam in the Malaysian Constitution,' MLJA, 1 (2009): 139. 
adalah terletak dalam bidang kuasa Negeri. Hal ini termasuklah keanggotaan, susunan dan tatacara Mahkamah Syariah yang hanya mempunyai bidang kuasa terhadap orang yang menganut agama Islam.

Secara umumnya, Mahkamah Syariah mempunyai bidang kuasa sivil dan jenayah yang berbeza antara bidang kuasa Mahkamah Rendah Syariah dan Mahkamah Tinggi Syariah. ${ }^{8}$ Kuasa Mahkamah Syariah untuk menjatuhkan hukuman ke atas pesalah jenayah Syariah adalah tertakluk kepada Akta Mahkamah Mahkamah Syariah (Bidang kuasa Jenayah) 1965 (Akta 355) iaitu Akta Persekutuan, ${ }^{9}$ yang mana Mahkamah Syariah hanya mempunyai bidang kuasa ke atas orang yang menganut agama Islam, serta mempunyai kuasa dalam menjatuhkan hukuman penjara tidak lebih tiga tahun, atau denda tidak melebihi RM5000.00, atau sebatan tidak melebihi enam kali, atau apa-apa gabungan hukuman tersebut. ${ }^{10}$

Secara asasnya, JKSM memainkan peranan penting dalam pembangunan atau inovasi di Mahkamah Syariah terutamanya melalui penglibatan pegawai Syariah, penyediaan prasarana, latihan dan penyelarasan dari aspek perundangan dan pentadbiran Mahkamah Syariah di seluruh Malaysia. Memandangkan hal ehwal agama Islam (termasuk Mahkamah Syariah) berada bawah bidang kuasa negeri, maka struktur kerja yang diperkenalkan oleh JKSM turut mendapat penerimaan yang berbeza dari setiap negeri yang secara umumnya dikenali sebagai negeri gunasama dan negeri bukan gunasama. ${ }^{11}$ Antara negeri yang bernaung bawah JKSM dalam skim gunasama ialah Selangor, Pulau Pinang, Negeri Sembilan, Perlis, Wilayah Persekutua Kuala Lumpur, Melaka dan Sabah. ${ }^{12}$ Sehubungan itu, terdapat Pegawai Syariah yang dilantik melalui JKSM di negeri-negeri gunasama tersebut. Hal ini berbeza dengan negerinegeri bukan gunasama yang mana pelantikan pegawai-pegawai Syariah di negeri-negeri berkenaan adalah melalui Setiausaha Kerajaan Negeri. Walaupun begitu, setiap negeri bukan gunasama tersebut telah menubuhkan JKSN yang

\footnotetext{
Sebagai contoh, lihat Seksyen 42 dan Seksyen 43 Enakmen Pentadbiran Perundangan Islam (Selangor) 1989.

9 Seksyen 2, Akta Mahkamah Mahkamah Syariah (Bidang kuasa Jenayah) 1965 (Akta 355).

10 Seksyen 2, Akta Mahkamah Mahkamah Syariah (Bidang kuasa Jenayah) 1965 (Akta 355).

11 Tuan Mohamad Shakir Abdul Hamid (Ketua Pendaftar, Jabatan Kehakiman Syariah Malaysia), dalam temu bual beliau bersama penulis pada 30 Mei 2016.

12 Tuan Mohamad Shakir Abdul Hamid (Ketua Pendaftar, Jabatan Kehakiman Syariah Malaysia), dalam temu bual beliau bersama penulis pada 30 Mei 2016.
} 
berperanan dalam memastikan kelancaran perjalanan pentadbiran Mahkamah Syariah di negeri masing-masing. ${ }^{13}$

Dalam mencapai visi dan misi JKSM bagi memartabatkan institusi kehakiman Syariah di Malaysia serta meningkatkan keseragaman dalam pentadbiran kehakiman Syariah di seluruh negara, JKSM telah mengatur strategi kerja bagi membolehkan pentadbiran Mahkamah Syariah dapat dilaksanakan dengan teratur, professional dan selari dengan tuntutan semasa permasalahan Syariah di negara ini. Antaranya termasuklah menggubal dasar bagi mempertingkatkan prestasi Mahkamah Syariah dan menyelaras kaedahkaedah, Arahan Amalan serta peraturan kepada semua pegawai Syariah di JKSM dan JKSN, serta kepada agensi-agensi lain yang berkait secara langsung dengan dasar, kaedah, Arahan Amalan atau peraturan tersebut. ${ }^{14}$ Selain itu juga, JKSM turut melakukan penyelidikan berkaitan sistem perundangan dan kehakiman Syariah bagi memastikan pentadbiran dan amalan semasa di Mahkamah Syariah terus mapan bagi berdepan dengan isu dan cabaran semasa. ${ }^{15}$ Sehubungan itu, kakitangan JKSM sentiasa diberi latihan melalui penganjuran kursus dan seminar bagi memantapkan pengetahuan dan kemahiran yang sedia ada termasuklah latihan yang berkaitan dengan perundangan, teknologi maklumat dan aspek-aspek lain yang boleh memberi nilai tambah kepada pembangunan modal insan kakitangan JKSM. ${ }^{16}$

Secara ringkasnya, JKSM dapat dianggap sebagai institusi induk yang menyelaras pentadbiran Mahkamah Syariah sama ada di negeri gunasama mahupun di negeri bukan gunasama bagi menyangga kemandirian institusi kehakiman Syariah di Malaysia.

\section{KEJAYAAN MODAL INSAN DAN INOVASI DALAM PENTADBIRAN MAHKAMAH SYARIAH}

Secara umumnya, JKSM telah mewujudkan beberapa inovasi dalam bentuk penambahbaikan perkhidmatan secara dalam talian bagi menepati keperluan semasa permasalahan yang berkaitan dengan penyelesaian kes di Mahkamah

13 Tuan Mohamad Shakir Abdul Hamid (Ketua Pendaftar, Jabatan Kehakiman Syariah Malaysia), dalam temu bual beliau bersama penulis pada 30 Mei 2016.

14 Tuan Mohamad Shakir Abdul Hamid (Ketua Pendaftar, Jabatan Kehakiman Syariah Malaysia), dalam temu bual beliau bersama penulis pada 30 Mei 2016.

15 Tuan Mohamad Shakir Abdul Hamid (Ketua Pendaftar, Jabatan Kehakiman Syariah Malaysia), dalam temu bual beliau bersama penulis pada 30 Mei 2016.

16 Tuan Mohamad Shakir Abdul Hamid (Ketua Pendaftar, Jabatan Kehakiman Syariah Malaysia), dalam temu bual beliau bersama penulis pada 30 Mei 2016. 
Syariah. Antara inovasi yang turut menyumbang kepada penyelesaian kes Syariah ialah amalan șulh yang mula diperkenalkan pada tahun 2002 melalui pembentukan Majlis Sulh. ${ }^{17}$ Amalan șulh di Mahkamah Syariah di Malaysia diinspirasikan daripada pendekatan penyelesaian kes dalam amalan mahkamah di Singapura dan pendekatannya diubah suai bagi direalisasikan dalam konteks amalan Mahkamah Syariah di Malaysia. Apa yang menarik, konsep penyelesaian kes secara șulh di Mahkamah Syariah di Malaysia turut diaplikasi oleh Biro Bantuan Guaman (BBG) dengan nama 'mediasi'. ${ }^{18}$

Sehingga kini, seramai 84 orang Pegawai Sulh yang menjadi nadi penggerak modal insan telah dilantik oleh Persekutuan dan Negeri. Dalam amalan ini, semua kes di Mahkamah Syariah akan melalui proses șulh kecuali kes pembubaran perkahwinan, pengesahan nasab, kes faraid dan kes jenayah Syariah. Selain itu juga, amalan ini turut menyelesaikan sesuatu pertikaian secara terbuka dan sukarela memandangkan proses penyelesaian kes melibatkan satu proses perundingan antara pihak-pihak yang dikendalikan secara terpimpin oleh Pegawai Sulh yang dilantik. Secara umumnya, lebih 50 peratus kes yang dibawa oleh pihak-pihak yang terlibat ke Mahkamah Syariah berjaya diselesaikan secara sulh..$^{19}$ Secara tidak langsung, penyelesaian kes melalui kaedah ini menjimatkan kos dan masa pihak-pihak yang terlibat memandangkan proses perbicaraan mahkamah yang panjang dapat dielakkan. ${ }^{20}$

Selain pembentukan Majlis Sulh, penyelesaian kes-kes mal terutamanya kes permohonan cerai oleh pihak isteri di Mahkamah Syariah turut dipengaruhi oleh pengenalan dan pemakaian HAKAM. Penyelesaian mealui kaedah 'tahkim' atau Hakam mula diperkenalkan pada tahun 2006 melalui Arahan Amalan No. 1 Tahun 2006. Lazimnya, apabila pihak isteri membuat permohonan cerai, permasalahan mula timbul apabila pihak suami enggan menceraikan isteri melalui lafaz talak dan enggan memberi kerjasama terhadap prosiding perceraian di Mahkamah Syariah. Dalam aspek modal insan yang dibincangkan dalam makalah ini, Hakam yang dilantik serta berperanan dalam meleraikan ketegangan yang wujud antara pihak suami dan isteri tersebut, serta mencari penyelesaian terbaik ekoran permohonan cerai pihak isteri dalam

17 Tuan Mohamad Shakir Abdul Hamid (Ketua Pendaftar, Jabatan Kehakiman Syariah Malaysia), dalam temu bual beliau bersama penulis pada 30 Mei 2016.

18 Tuan Mohamad Shakir Abdul Hamid (Ketua Pendaftar, Jabatan Kehakiman Syariah Malaysia), dalam temu bual beliau bersama penulis pada 30 Mei 2016.

19 Tuan Mohamad Shakir Abdul Hamid (Ketua Pendaftar, Jabatan Kehakiman Syariah Malaysia), dalam temu bual beliau bersama penulis pada 30 Mei 2016.

20 Tuan Mohamad Shakir Abdul Hamid (Ketua Pendaftar, Jabatan Kehakiman Syariah Malaysia), dalam temu bual beliau bersama penulis pada 30 Mei 2016. 
kes berkenaan merupakan suatu kejayaan yang wajar diiktiraf dalam konteks penyelesaian kes di Mahkamah Syariah.

Antara keadaan lain yang diperuntukkan dalam Arahan Amalan No. 1 Tahun 2006 yangg membolehkan penyelesaian kes melalui kaedah Hakam termasuklah:

a) perbalahan di antara suami isteri itu kadangkala terbitnya dengan sebab nusyuz isteri, atau dengan sebab kezaliman suami, atau dengan terbit kesamaran siapa yang benar di antara kedua-duanya atau berpunca dari kedua-duanya, berdusta atau menuntut yang bukan hak;

b) perbalahan di antara suami isteri dan sukar keduanya menjalankan aturan Allah yang ditetapkan atas suami isteri itu, tuduh menuduh mengenai masing-masing tidak melaksanakan hak-hak sebagai suami isteri;

c) isteri atau suami menuduh di antara keduanya berkawan dengan perempuan/lelaki yang telah melampaui hukum Syarak;

d) sering berlaku pertikaian hingga pukul memukul;

e) salah seorang keluar dari rumah kediaman, tidak tinggal bersama sedangkan punca sebenar tidak dapat dibuktikan oleh kedua-dua belah pihak di hadapan mahkamah;

f) tuduh menuduh di antara suami isteri mengenai anak-anak berkaitan dengan tanggungjawab masing-masing sehingga berlaku pertengkaran dan perselisihan yang berpanjangan;

g) jika didapati bahawa aduan isteri itu tidak sabit dan ditolak Mahkamah dengan sebab ia tidak dapat membuktikan kebenarannya dan kemudian daripada itu isteri berulang-ulang membuat aduan dan Mahkamah mendapati pertikaian sentiasa berlaku di antara suami isteri tersebut,

h) apa-apa tindakan yang menyebabkan darar syarie ke atas isteri $^{21}$

Sebelum tahun 2008, masyarakat dimomokkan dengan tanggapan bahawa Mahkamah Syariah "umpama harimau ketiadaan taring" rentetan kelemahan penguatkuasaan perintah nafkah isteri dan anak-anak apabila

21 Perenggan 3, Amalan Hakam Mahkamah Syariah. 
sesuatu kes perceraian diputuskan. Tanggapan tersebut berpunca daripada pengabaian kebajikan golongan wanita dan kanak-kanak yang sering berlaku apabila bekas suami dan bapa tersebut culas menjalankan tanggungjawab pembayaran nafkah sebagaimana yang telah diputuskan dan diperintahkan oleh Hakim Syarie. Sehubungan itu, JKSM secara rasminya telah menubuhkan Bahagian Sokongan Keluarga (BSK) pada tahun 22 Oktober 2019.22 Dengan bersumberkan dana awal sebanyak RM 500,000.00 daripada Majlis Agama Islam Wilayah Persekutuan (MAIWP), penubuhan BSK dianggap sebagai salah satu daripada inovasi terbesar yang pernah dilakukan oleh JKSM, sekali gus mengembalikan perspektif positif masyarakat kepada pentadbiran dan pelaksanaan perintah Mahkamah Syariah dalam menjaga kebajikan pihakpihak yang berkenaan. ${ }^{23}$ Sebanyak 96 perjawatan dalam BSK telah diwujudkan hasil dari cadangan penstrukturan semula JKSM yang telah diluluskan olehb Jabatan Perkhidmatan Awam Malaysia (JPA) bagi mewujudkan kelompok modal insan yang menjamin operasi BSK secara bersepadu di seluruh Malaysia. ${ }^{24}$

Menyedari kepentingan penjagaan kebajikan pihak-pihak yang terlibat, terutamanya golongan wanita, pihak JKSM telah mewujudkan BSK Transit yangh dikendalikan dan diselenggarakan secara langsung BSK. Kewujudan BSK Transit yang berperanan sebagai tempat penginapan sementara pihakpihak, khususnya wanita yang menghadiri prosiding di Mahkamah Syariah dilihat sebagai perkhidmatan yang amat membantu mempercepatkan pengendalian kes mal di Mahkamah Syariah. Bahkan secara tidak langsung, perkhidmatan pengangkutan dan penyediaan makan dan minum secara percuma kepada pihak yang menggunakan perkhidmatan BSK Transit dilihat sebagai usaha positif pihak JKSM dalam usaha memberikan sokongan moral kepada pihak yang terlibat secara langsung dalam pertikaian kes mal di Mahkamah Syariah. Bagi mempercepatkan urusan permohanan, semakan dan kelulusan penggunaan perkhidmatan BSK Transit ini, satu lagi inovasi telah diwujudkan oleh JKSM iaitu Easy Transit yang merupakan satu sistem yang dibangun secara in house pada awal 2015. Pada tahun 2016, penambahbaikan telah dilakukan terhadap sistem ini dengan meningkatkan keupayaan memuat

Tuan Mohamad Shakir Abdul Hamid (Ketua Pendaftar, Jabatan Kehakiman Syariah Malaysia), dalam temu bual beliau bersama penulis pada 30 Mei 2016.

23 Tuan Mohamad Shakir Abdul Hamid (Ketua Pendaftar, Jabatan Kehakiman Syariah Malaysia), dalam temu bual beliau bersama penulis pada 30 Mei 2016.

24 Tuan Mohamad Shakir Abdul Hamid (Ketua Pendaftar, Jabatan Kehakiman Syariah Malaysia), dalam temu bual beliau bersama penulis pada 30 Mei 2016. 
naik dokumen bagi menyokong keperluaan penggunaan Easy Transit selaras dengan perluasan penggunaan BSK Transit itu sendiri. ${ }^{25}$

Seiring dengan kemajuan komunikasi dalam dunia global kini, JKSM telah membangunkan beberapa sistem bagi melancarkan pentadbiran dan meningkatkan profesionalism modal insan di Mahkamah Syariah di Malaysia. Antaranya ialah pembangunan sistem E-Faraid yang dianggap signifikan dalam pengurusan dan penyelesaian kes tuntutan faraid di Mahkamah Syariah bermula dari peringkat pendaftaran kes hingga ke peringkat pengeluaran perintah faraid. Sistem ini membantu mempercepatkan proses pendaftaran kes kerana setiap maklumat yang berkaitan dengan tuntutan tersebut, seperti nombor kad pengenalan si mati, tarikh kematian, nombor sijil kematian, alamat waris dan seumpamanya dihubungkan dan disemak secara langsung dengan Jabatan Pendaftaran Negara (JPN) secara dalam sistem. Memandangkan sistem ini mampu menjana kiraan dan pembahagian harta faraid kepada wariswaris yang berhak hingga seratus lapis waris, maka sistem ini membolehkan hakim memutuskan kes faraid secara cepat dan efisien. ${ }^{26}$

Selain itu juga, JKSM telah membentuk satu portal K-Faraid yang memuatkan ilmu faraid yang lengkap dengan pendapat fuqaha berkenaan imu tersebut. Portal tersebut bukan hanya boleh diakses oleh kakitangan JKSM, bahkah turut boleh diakses oleh Mahkamah Syariah seluruh negara dan orang awam secara umumnya. ${ }^{27}$

Bersesuaian dengan fungsi Mahkamah Syariah yang mengadili kes bersumberkan hukum Syarak, JKSM telah mewujudkan Nas Portal yang memuatkan nas al-Quran, Hadis dan pendapat fuqaha berdasarkan kod kes mal dan jenayah Syariah yang diguna pakai di seluruh Mahkamah Syariah di Malaysia. Kewujudan portal ini boleh dianggap sebagai satu gerbang informasi atau pangkalan data yang memudahkan rujukan pengamal perundangan Syariah, ahli akademik, penyelidik, pelajar perundangan Syariah dan orang awam. ${ }^{28}$

25 Tuan Mohamad Shakir Abdul Hamid (Ketua Pendaftar, Jabatan Kehakiman Syariah Malaysia), dalam temu bual beliau bersama penulis pada 30 Mei 2016.

26 Tuan Mohamad Shakir Abdul Hamid (Ketua Pendaftar, Jabatan Kehakiman Syariah Malaysia), dalam temu bual beliau bersama penulis pada 30 Mei 2016.

27 Tuan Mohamad Shakir Abdul Hamid (Ketua Pendaftar, Jabatan Kehakiman Syariah Malaysia), dalam temu bual beliau bersama penulis pada 30 Mei 2016.

28 Tuan Mohamad Shakir Abdul Hamid (Ketua Pendaftar, Jabatan Kehakiman Syariah Malaysia), dalam temu bual beliau bersama penulis pada 30 Mei 2016. 
Usaha JKSM dalam mewujudkan inovasi-inovasi tersebut ternyata bukan sahaja memberi impak yang positif terhadap penyelesaian kes-kes Syariah, bahkan turut mendapat pengiktirafan pada peringkat kebangsaan dan antarabangsa. Sebagai contoh, antara anugerah yang paling signifikan dalam usaha memperkenalkan sistem-sistem baharu dalam pentadbiran Mahkamah Syariah ialah Hadiah Pertama bagi Anugerah Kualiti Teknologi Maklumat dan Komunikasi (AKICT) pada tahun 2007 melalui projek E-Syariah, iaitu projek Kerajaan Elektronik yang ketujuh bawah Aplikasi Perdana Koridor Raya Multimedia (MSC). ${ }^{29}$ Sistem ini merupakan satu sistem pengurusan kes yang bersepadu yang mengintegrasikan semua proses yang terlibat dalam pengendalian kes di Mahkamah Syariah. Melalui sistem ini, penyelarasan dan perkongsian maklumat dalaman dilaksanakan secara sistematik memandangkan sistem ini mewujudkan satu rangkaian elektronik yang menghubungkan Mahkamah-mahkamah Syariah Negeri dengan JKSM serta agensi-agensi yang berkaitan dengan operasi atau perjalanan pentadbiran Mahkamah Syariah di Malaysia. ${ }^{30}$ Antara aplikasi lain yang diwujudkan dalam sistem E-Syariah ialah Sistem Pengurusan Kes Mahkamah Syariah, Portal E-Syariah, e-Nafkah, e-Bicara, e-Faraid, Sistem Automasi Pejabat, Sistem Pengurusan Perpustakaan dan Sistem pendaftaran Peguam Syarie. Oleh sebab itu, sistem ini pernah mendapat Anugerah Portal Kerajaan Elektronik Terbaik dalam satu kajian "Benchmarking and Comparative Study of Malaysia Government Portals and Websites 2005". ${ }^{31}$

Manakala pada peringkat negeri, beberapa inovasi yang dibuat turut mendapat pengiktirafan, antaranya Anugerah Emas dan ICC Muda terbaik pada Mini Konvensyen Team Excellence Wilayah Tengah anjuran Perbadanan Produktiviti Malaysia (MPC) pada 26April 2016 yang diterima oleh Mahkamah Syariah Wilayah Persekutuan melalui Projek E-Fos (E-Fast.Order.Sulh). Projek ini dilaksanakan bagi menambahbaik proses kerja șulh yang mana perintah șulh dapat dikeluarkan dalam tempoh sejam selepas pengendorsan. ${ }^{32}$ Ini bagi memastikan kes dapat diselesaikan dengan cepat, melupuskan kes tertunggak dan mengurangkan kelewatan kes. ${ }^{33}$

29 Tuan Mohamad Shakir Abdul Hamid (Ketua Pendaftar, Jabatan Kehakiman Syariah Malaysia), dalam temu bual beliau bersama penulis pada 30 Mei 2016.

30 Tuan Mohamad Shakir Abdul Hamid (Ketua Pendaftar, Jabatan Kehakiman Syariah Malaysia), dalam temu bual beliau bersama penulis pada 30 Mei 2016.

31 Tuan Mohamad Shakir Abdul Hamid (Ketua Pendaftar, Jabatan Kehakiman Syariah Malaysia), dalam temu bual beliau bersama penulis pada 30 Mei 2016.

32 Tuan Mohamad Shakir Abdul Hamid (Ketua Pendaftar, Jabatan Kehakiman Syariah Malaysia), dalam temu bual beliau bersama penulis pada 30 Mei 2016.

33 Tuan Mohamad Shakir Abdul Hamid (Ketua Pendaftar, Jabatan Kehakiman Syariah Malaysia), dalam temu bual beliau bersama penulis pada 30 Mei 2016. 
Selain itu juga, Mahkamah Syariah Wilayah Persekutuan turut melaksanakan inovasi projek Kaunter D.I.Y merupakan inovasi yang diilhamkan daripada projek inovasi E-Shariah Instant Access Procedure (E-Siap) di Mahkamah Syariah Pulau Pinang yang mana bertujuan untuk memberikan pilihan kepada pelanggan Mahkamah Syariah untuk menyediakan pliding mereka sendiri dengan kos yang lebih rendah berpandukan template yang telah disediakan. Walaupun projek inovasi ini masih beum menerima pengiktirafan dan anugerah, projek ini masih boleh dianggap sebagai satu inovasi yang baik dan memberi sumbangan yang positif terhadap pengurusan atau perjalanan kes di Mahkamah Syariah memandangkan projek E-Siap yang dilaksanakan di Mahkamah Syariah Pulau Pinang (iaitu projek inovasi yang sama tetapi menggunakan nama yang berbeza) telah menerima beberapa pengiktirafan dan anugerah yang membanggakan. Antaranya ialah Anugerah Ketua Pengarah MAMPU 2015, Johan Konvensyen Kumpulan Kreatif dan Inovatif Peringkat Negeri Pulau Pinang 2015, Anugerah Emas dalam Pertandingan Konvensyen Team Excellence Wilayah Sabah \& Sarawak 2015 serta Anugerah 3 Bintang (Emas) Annual Productivity \& Innovation Conferece (APIC) 2015.34

Manakala Mahkamah Syariah Terengganu pula melaksanakan projek inovasi EZNafkah, yang mana bertujuan mempercepatkan proses permohonan bantuan nafah anak kepada yang berhak dalam prosiding penguatkuasaan perintah nafkah anak di Seksyen Bahagian Sokongan keluarga Terengganu. Inovasi ini berjaya meraih anugerah pada peringkat antarabangsa apabila memenangi Anugerah Emas dalam International Conference on Quality 2014 yang bertempat di Shinjuku, Tokyo, Jepun. ${ }^{35}$

Dalam sesebuah tadbir urus, kombinasi inovasi yang positif dan modal insan yang cemerlang mampu membuahkan pencapaian yang baik dalam mencapai sesuatu misi dan visi sesebuah institusi. Keadaan ini turut tercermin dalam pentadbiran undang-undang Syariah semasa apabila bilangan Pegawai Syariah yang sedang berkhidmat bukan hanya memiliki taraf pendidikan yang baik, bahkan bilangan pegawai yang telah menamatkan pengajian peringkat Doktor Falsafah semakin bertambah. Sebagai contoh, YAA Dato' Dr. Mohd Na'im Mokhtar merupakan Hakim Syarie pertama di Malaysia yang memperolehi Doktor Falsafah ${ }^{36}$ dan turut aktif menyumbang idea dan buah fikiran hingga

34 Tuan Mohamad Shakir Abdul Hamid (Ketua Pendaftar, Jabatan Kehakiman Syariah Malaysia), dalam temu bual beliau bersama penulis pada 30 Mei 2016.

35 Tuan Mohamad Shakir Abdul Hamid (Ketua Pendaftar, Jabatan Kehakiman Syariah Malaysia), dalam temu bual beliau bersama penulis pada 30 Mei 2016.

36 Ferzalfie Fauzi, 'Mohd. Na'im, 'Hakim Mahkamah Syariah Pertama Peroleh PhD,' Utusan Malaysia, http://ww1.utusan.com.my/utusan/info. asp? $=2007 \& \mathrm{dt}=0812 \& p u b=$ Utusan_Malaysia\&sec=Dalam_Negeri\&pg $=\mathrm{dn} \_01$. htm, dicapai pada 12 Ogos 2007. 
ke peringkat antarabangsa. ${ }^{37}$ Pencapaian beliau dalam memperolehi Doktor Falsafah seolah-olah menjadi inspirasi kepada Pegawai Syariah lain yang sedang berkhidmat dalam institusi yang sama apabila bilangan pegawai yang telah dan sedang megikuti pengajian pada peringkat Doktor Falsafah semakin bertambah. Antaranya yang terkini, Dr. Jazilah Mohd Saad@Mat Saud yang merupakan salah satu modal insan JKSM. Selain itu juga, bilangan modal insan di JKSM yang telah menamatkan pengajian Sarjana dan bakal menyusul ke pengajian peringkat pengajian Doktor Falsafah turut meningkat dari semasa ke semasa. ${ }^{38}$

Selain itujuga, JKSM turut menganjak persepsi negatif segelintir masyarakat terhadap potensi wanita yang boleh memegang jawatan Hakim Syarie apabila hakim wanita turut dilantik sebagai hakim di Mahkamah Syariah dalam melengkapkan keperluan modal insan yang sedia ada walaupun ada segelintir masyarakat yang masih ragu-ragu dengan keupayaan mereka. ${ }^{39}$ Apa yang lebih membanggakan, pelantikan tersebut dibuat bukan sahaja kerana mengambil kira pendapat atau perbahasan hukum mengenai pelantikan wanita sebagai hakim, bahkan turut mengambil kira kebolehan, potensi dan latar belakang pendidikan mereka. ${ }^{40}$ Hal ini jelas menonjolkan bahawa inovasi yang mantap sahaja tidak mampu membawa sesebuah institusi maju ke hadapan tanpa kewujudan modal insan yang cemerlang bukan hanya dari segi pengurusan dan peribadi, bahkan dari segi intelek dan kebolehsediaan untuk memacu

37 YAA Dato' Dr. Mohd Na'im Mokhtar pernah dilantik sebagai dilantik sebagai Malaysian Cheavening Visiting Fellow Oxford University, United Kingdom bagi tahun 2008/2009 serta pernah dilantik sebagai Visiting Fellow di Harvard Law School, Harvard University, Amerika Syarikat. Selain itu juga, beliau turut aktif membentangkan kertas kerja dalam forum dan seminar tempatan dan antarabangsa berkenaan topik atau subjek Undang-undang Islam (Syariah), serta turut menganggotai Lembaga Penasihat Syariah bank-bank Islam tempatan dan bank asing serta Syarikat Takaful seperti CIMB Islamic Bank, Salihin Trustee Bhd dan American and British Investment Bank (Mauritius).

38 Tuan Mohamad Shakir Abdul Hamid (Ketua Pendaftar, Jabatan Kehakiman Syariah Malaysia), dalam temu bual beliau bersama penulis pada 30 Mei 2016.

39 Norrasyidah Arshad, 'Selangor Lantik Wanita Hakim Mahkamah Tinggi Syariah,' Berita Harian, http://www.bharian.com.my/node/168766, dicapai pada 27 Jun 2016. Lihat juga Salleh Buang, 'Hakim Wanita di Mahkamah Syariah,' Utusan Malaysia, $\quad$ http://www.utusan.com.my/rencana/hakim-wanita-di-mahkamahsyariah-1.195374, dicapai pada 29 Februari 2016.

40 Bernama, 'Akhirnya, Mahkamah Tinggi Syariah Lantik Dua Hakim Wanita Pertama,' http://www.themalaymailonline.com/projekmmo/berita/article/ akhirnya-mahkamah-tinggi-syariah-lantik-dua-hakim-wanita-pertama, dicapai pada 24 September 2016. 
institusi, terutamanya institusi yang mengangkat undang-undang Islam seperti Mahkamah Syariah untuk seiring dengan perjalanan dunia global.

\section{KEMANDIRIAN MAHKAMAH SYARIAH DI MALAYSIA SEBAGAI MODEL ANTARABANGSA}

Bagi berdiri sebagai sebuah institusi Syariah yang mampu menjadi suatu model pada peringkat antarabangsa dan menongkah cabaran dunia global dalam penguatkuasaan dan pelaksanaan undang-undang Islam, Mahkamah Syariah di Malaysia bukan hanya perlu maju atau ke hadapan dari segi tadbir urus, bahkan turut perlu ke hadapan dari segi penggunaan dan pembangunan teknologi maklumat. Hal ini turut disentuh oleh Tan Sri Sheikh Ghazali bin $\mathrm{Hj}$. Abdul Rahman, ${ }^{41}$ yang mana beliau berpandangan bahawa sistem penyampaian perkhidmatan di institusi Syariah perlu segera dipertingkatkan bagi membolehkan institusi tersebut terus mapan dan mandiri dalam mendepani cabaran semasa yang berkaitan dengan penguatkuasaan dan pelaksanaan undang-undang Islam dalam dunia global.

Sehubungan itu, inovasi yang telah diwujudkan di dalam pentadbiran Mahkamah Syariah dan anugerah yang telah diterima melalui pencapaian tersebut dilihat mampu meningkatkan kemandirian Mahkamah Syariah di Malaysia dan seterusnya menjadi model Mahkamah Syariah bagi negara lain. Walaupun inovasi yang sedia dilaksanakan di Mahkamah Syariah tersebut mungkin tidak mampu menyelesaikan cabaran yang dihadapi dalam pelaksanaan undang-undang Islam dan tadbir urus Mahkamah Syariah secara holistik, hal tersebut dilihat sebagai suatu batu loncatan dalam menganjak perspektif masyarakat yang lebih positif terhadap Mahkamah Syariah. ${ }^{42}$

Bagi memantapkan, menyelaraskan serta mempercepatkan penyelesaian kes di Mahkamah Syariah, pihak JKSM turut mengeluarkan Arahan Amalan yang dikeluarkan setelah melalui suatu perbincangan dalam Mesyuarat Jawatankuasa Induk Arahan Amalan Mahkamah Syariah. Arahan Amalan ini diguna pakai di Mahkamah Syariah dan berperanan sebagai rujukan Hakim Syarie dan Pegawai Syariah dalam mengendalikan dan menyelesaikan kes di Mahkamah Syariah. Arahan Amalan tersebut merangkumi perkara yang berhubung dengan tadbir urus yang berkesan yang membantu menyeragamkan pentadbiran Mahkamah Syariah di seluruh Malaysia, misalnya, Arahan

41 Sheikh Ghazali Abdul Rahman, 'Peranan Institusi Syariah dalam Menghadapi Cabaran Era Globalisasi,' Jurnal Hukum, vol. 27, no. 2 (2009): 175-182.

42 Tuan Mohamad Shakir Abdul Hamid (Ketua Pendaftar, Jabatan Kehakiman Syariah Malaysia), dalam temu bual beliau bersama penulis pada 30 Mei 2016. 
Amalan Penangguhan Kes Atas Alasan Cuti Sakit, ${ }^{43}$ Arahan Amalan Prosedur Menghidupkan Semula Kes Yang Telah Dibuang/Ditolak Sebelum Selesai, ${ }^{44}$ Arahan Amalan Kod Warna Bagi Rekod Rayuan Mahkamah Syariah Seluruh Malaysia ${ }^{45}$ dan seumpamanya. Selain itu juga, Arahan Amalan ini turut diguna pakai sebagai rujukan di Mahkamah Syariah dalam membantu Hakim Syarie membuat keputusan terutamanya dalam hal berkenaan prosedur sekiranya prosedur berkenaan sesuatu kes yang ditangani tidak terdapat dalam undangundang prosedur atau undang-undang substantif yang sedia ada. Sebagai contoh, Arahan Amalan Penggunaan Lafaz Sumpah Istizhar Dalam Kes Mal, ${ }^{46}$ Arahan Amalan Penentuan Mahkamah Yang Berbidang kuasa Membicarakan Kes-kes Harta Sepencarian, ${ }^{47}$ Arahan Amalan Penentuan Kes Yang Perlu Dirujuk Ke Majlis Șulh Pada Peringkat Pendaftaran Kes, ${ }^{48}$ Arahan Amalan Penggunaan Aplikasi E-Bicara Oleh Hakim Syarie, ${ }^{49}$ Arahan Amalan Garis Panduan Penulisan Teks Penghakiman, ${ }^{50}$ Arahan Amalan Kehadiran Salah Satu Pihak di Hadapan Hakim Semasa Perintah Persetujuan Dibuat ${ }^{51}$ dan seumpamanya.

Selain dari inovasi dan penambahbaikan modal insan pada peringkat lokal, JKSM turut terlibat dalam penambahbaikan modal insan pada peringkat antarabangsa atau global. Hal ini dapat dilihat pada proses silang kerjasama dari sudut perkongsian kepakaran Pegawai Syariah Malaysia kepada pihak luar. Misalnya, Unit Perundangan Islam Kementerian Hal Ehwal Ugama Negara Brunei Darussalam telah mendapatkan kepakaran pihak JKSM yang diwakili oleh Dato' Dr. Mohd Na'im Mokhtar bagi mengendalikan Kursus Pembangunan Kemahiran lebih 50 orang pengamal Undang-undang Syariah dan sivil, pegawai kementerian Pertahanan, Kementerian Hal Ehwal Agama, Polis Diraja Brunei dan agensi-agensi lain di negara tersebut secara berkala antara November 2010 sehingga Februari 2011. Kursus tersebut melibatkan perkongsian berkenaan undang-undang dan amalan dalam Acara Mal dan

\footnotetext{
43 Arahan Amalan JKSM No. 3 Tahun 2004.

44 Arahan Amalan JKSM No. 12 Tahun 2005.

45 Arahan Amalan JKSM No. 6 Tahun 2012.

46 Arahan Amalan JKSM No. 1 Tahun 2003.

47 Arahan Amalan JKSM No. 6 Tahun 2003.

48 Arahan Amalan JKSM No. 1 Tahun 2010.

49 Arahan Amalan JKSM No. 6 Tahun 2013.

50 Arahan Amalan JKSM No. 2 Tahun 2015.

51 Arahan Amalan JKSM No. 9 Tahun 2015.
} 
Acara Jenayah bermula dari proses sebelum perbicaraan hingga proses pasca penghakiman. ${ }^{52}$

Selain dari menghantar wakil JKSM dalam menyampaikan kepakaran yang ada pada Pegawai Syariah, JKSM juga turut menerima lawatan atau kunjungan hormat dalam mendapatkan input terkini dalam pelaksanaan dan amalan undang-undang Syariah di Malaysia. Negara Brunei Darussalam, misalnya, telah membuat beberapa siri lawatan ke Malaysia untuk mempelajari usaha atau peningkatan khidmat yang telah dibuat oleh JKSM untuk dilaksanakan di negara tersebut. Hasil daripada lawatan tersebut, Brunei kini dalam proses menubuhkan Mahkamah Sulh dan juga mewujudkan penggunaan teknologi maklumat di Jabatan Kehakiman Negara Brunei Darussalam dalam masa terdekat. ${ }^{53}$ Selain Brunei, JKSM juga turut menerima kunjungan lawatan deligasi daripada negara lain dengan tujuan yang sama. Antaranya ialah Kementerian Kehakiman Thailand, Kementerian Kehakiman Gambia, Kementerian keadilan Jordan, Kementerian Keadilan Arab Saudi, Kementerian Keadilan Kuwait, Pemerintah Profinsi Daerah Khusus Ibu Kota Jakarta, Pengadilan Tinggi Agama Surabaya, Kyushu Federation of Bar Associations Japan serta Hunan Legislative \& Regional Administrative Research Centre, International Education Centre Hunan, China. ${ }^{54}$ Selain itu, pengamal perundangan, termasuklah hakim dan peguam daripada beberapa lain seperti Brunei, Indonesia, Oman, Nigeria, Afghanistan, Yaman, Sudan dan Qatar turut mengunjungi JKSM dalam langkah memperolehi maklumat berkenaan amalan undang-undang Syariah di Malaysia. ${ }^{55}$ Proses ini jelas menunjukkan bahawa JKSM berperanan secara global dalam mengantarabangsakan undang-undang Islam, dan sekali gus memperlihatkan bahawa pentadbiran Mahkamah Syariah di Malaysia mampu menjadi model kepada pentadbiran undang-undang Islam pada peringkat antarabangsa.

52 Jabatan Kehakiman Syariah Malaysia. (n.d.). Perkongsian kepakaran JKSM demi pembangunan kemahiran Perundangan Syariah di Brunei. Didapatkan semula pada 24 September 2016 dari http://www.esyariah.gov.my/

53 Ustaz Awang Haji Salim Haji Besar (YAA Pehin Orang Kaya Paduka Seri Utama Datuk Paduka Setia, Ketua Hakim Syarie, Negara Brunei Darussalam), dalam temu bual beliau bersama penulis pada 22 September 2016.

54 Ustaz Awang Haji Salim Haji Besar (YAA Pehin Orang Kaya Paduka Seri Utama Datuk Paduka Setia, Ketua Hakim Syarie, Negara Brunei Darussalam), dalam temu bual beliau bersama penulis pada 22 September 2016.

55 Tuan Mohamad Shakir Abdul Hamid (Ketua Pendaftar, Jabatan Kehakiman Syariah Malaysia), dalam temu bual beliau bersama penulis pada 30 Mei 2016. 


\section{PENUTUP}

Setakat ini, pentadbiran Mahkamah Syariah telah mencapai satu tahap globalisasi dari segi pentadbiran dan pengurusan kes-kes mal dan jenayah. Masyarakat juga telah mengiktiraf kewujudan dan keberkesanan Mahkamah Syariah dalam menyelesaikan kes-kes kekeluargaan dalam kalangan masyarakat Islam. ${ }^{56}$ Cuma persoalannya sekarang ialah bagaimanakah cara untuk memaksimumkan pemahaman, pendedahan dan seterusnya mendapat pengiktirafan dari masyarakat tentang bidang kuasa Mahkamah Syariah, prosedur-prosedur di Mahkamah Syariah, serta peranan jabatan-jabatan agama dan agensi-agensi Islam lain di Malaysia dalam mengunggulkan lagi sistem perundangan dan kehakiman Islam di Malaysia. Antara faktor penting untuk mendapat pengiktirafan ialah dengan memahamkan masyarakat bahawa isu agama Islam dan Mahkamah Syariah bukan isu pada peringkat negeri sahaja, bahkan isu tersebut merupakan isu peringkat Persekutuan berdasarkan kepada Perkara 3 Perlembagaan Malaysia. Kedudukan agama Islam, perundangan Syariah dan Mahkamah Syariah di dalam negara kita agak kukuh dan signifikan $^{57}$ berdasarkan kepada Perkara 3 dan peruntukan-peruntukan lain dalam Perlembagaan Persekutuan.

Berdasarkan penelitian terhadap aspek modal insan dan inovasi di Mahkamah Syariah, makalah ini menyimpulkan bahawa kedua-dua aspek ini merupakan elemen penting dalam menyangga kecemerlangan pentadbiran Mahkamah Syariah. Bahkan, kewujudan kedua-dua aspek tersebut perlu saling selari dalam menjadikan Mahkamah Syariah sebagai satu institusi perundangan dan kehakiman Islam yang menyerlah pada pandangan masyarakat umum, terutamanya dalam konteks masyarakat majmuk seperti Malaysia. Sehubungan itu, makalah ini menyimpulkan bahawa kejayaan pentadbiran Mahkamah Syariah dalam konteks modal insan dan inovasi yang telah dilakukan oleh pihak JKSM dan JKSN merupakan suatu pencapaian yang wajar diiktiraf dan boleh dijadikan model pada peringkat antarabangsa. Dalam maksud lain, kejayaan pentadbiran Mahkamah Syariah dalam aspek-aspek tersebut boleh dijadikan ikutan oleh negara-negara lain dalam meningkatkan kualiti pentadbiran Mahkamah Syariah masing-masing dalam menegakkan keadilan yang berasaskan Syariah.

\footnotetext{
56 Sheikh Ghazali Haji Abdul Rahman, 'Masa Depan Mahkamah Syariah di Malaysia: Cabaran dan Strategi dalam Masyarakat Majmuk,' Jurnal Hukum, vol. 23, no. 2 (2007): 188-189.

57 Abdul Aziz Bari, 'Kedudukan Syariah dalam Perlembagaan Persekutuan,' Jurnal Hukum, vol. 26, no. 2 (2008): 174-175.
} 


\section{RUJUKAN}

Abdul Aziz Bari, 'Kedudukan Syariah dalam Perlembagaan Persekutuan,' Jurnal Hukum, vol. 26, no. 2 (2008): 169-179.

Bernama, 'Akhirnya, Mahkamah Tinggi Syariah Lantik Dua Hakim Wanita Pertama,' http:/www.themalaymailonline.com/projekmmo/berita/ article/akhirnya-mahkamah-tinggi-syariah-lantik-dua-hakim-wanitapertama, dicapai pada 24 September 2016.

Faiza Thamby Chik, 'Malay and Islam in the Malaysian Constitution,' $M L J A$, 1 (2009).

Ferzalfie Fauzi, 'Mohd. Na'im, 'Hakim Mahkamah Syariah Pertama Peroleh PhD,' Utusan Malaysia, http:/ww1.utusan.com.my/utusan/ info.asp $? \mathrm{y}=2007 \& \mathrm{dt}=0812 \& \mathrm{pub}=$ Utusan_Malaysia\&sec $=$ Dalam Negeri\&pg=dn_01.htm, dicapai pada 12 Ogos 2007.

Jabatan Kehakiman Syariah Malaysia. (n.d.). Perkongsian kepakaran JKSM demi pembangunan kemahiran Perundangan Syariah di Brunei. Retrieved September 24, 2016, from http://www.esyariah.gov.my/

Naquib al Attas, Preliminary Statement on A General Theory of the Islamicization of the Malay-Indonesian Archipelago (Kuala Lumpur: Dewan Bahasa dan Pustaka, 1969).

Nik Ahmad Kamal Nik Mahmood, 'Kedudukan Undang-Undang Islam dalam Perlembagaan Malaysia,' Al Ahkam, vol. 4 (1994), 2-3.

Norrasyidah Arshad, 'Selangor Lantik Wanita Hakim Mahkamah Tinggi Syariah,' Berita Harian, http://www.bharian.com.my/node/168766, dicapai pada 27 Jun 2016.

Ramizah Wan Muhammad, 'The Administration of Syariah Court in Malaysia, 1957-2009,' Journal of Islamic Law and Culture, vol. 13, no. 2-3 (2011): 242-252.

Salleh Buang, 'Hakim Wanita di Mahkamah Syariah,' Utusan Malaysia, http://www.utusan.com.my/rencana/hakim-wanita-di-mahkamahsyariah-1.195374, dicapai pada 29 Februari 2016.

Sheikh Ghazali Haji Abdul Rahman, 'Masa Depan Mahkamah Syariah di Malaysia: Cabaran dan Strategi dalam Masyarakat Majmuk,' Jurnal Hukum, vol. 23, no. 2 (2007): 188-189.

Sheikh Ghazali Haji Abdul Rahman, 'Peranan Institusi Syariah dalam Menghadapi Cabaran Era Globalisasi,' Jurnal Hukum, vol. 27, no. 2 (2009): 171-184. 


\section{Statut}

Akta Mahkamah Mahkamah Syariah (Bidang kuasa Jenayah) 1965

Amalan Hakam Mahkamah Syariah

Arahan Amalan JKSM No. 1 Tahun 2003

Arahan Amalan JKSM No. 1 Tahun 2010

Arahan Amalan JKSM No. 12 Tahun 2005

Arahan Amalan JKSM No. 2 Tahun 2015

Arahan Amalan JKSM No. 3 Tahun 2004

Arahan Amalan JKSM No. 6 Tahun 2003

Arahan Amalan JKSM No. 6 Tahun 2012

Arahan Amalan JKSM No. 6 Tahun 2013

Arahan Amalan JKSM No. 9 Tahun 2015

Enakmen Pentadbiran Perundangan Islam (Selangor) 1989

\section{Temu bual}

Tuan Mohamad Shakir Abdul Hamid (Ketua Pendaftar, Jabatan Kehakiman Syariah Malaysia), dalam temu bual beliau bersama penulis pada $30 \mathrm{Mei}$ 2016.

UstazAwang Haji Salim Haji Besar(YAAPehin Orang Kaya Paduka Seri Utama Datuk Paduka Setia, Ketua Hakim Syarie, Negara Brunei Darussalam), dalam temu bual beliau bersama penulis pada 22 September 2016. 